\title{
Item Parameter Estimation for Dichotomous Items Based on Item Response Theory: Comparison of BILOG-MG, Mplus and R (ltm)*
}

\author{
Şeyma UYAR *** Neşe ÖZTÜRK GÜBEŞ ***
}

\begin{abstract}
The aim of this study is twofold. The first one is to investigate the effect of sample size and test length on the estimation of item parameters and their standard errors for the two parameter item response theory (IRT). Another is to provide information about the performance of Mplus, BILOG-MG and R (ltm) programs in terms of parameter estimation under the conditions which were mentioned above. The simulated data were used in this study. The examinee responses were generated by using the open-source program R. After obtaining the data sets, the parameters were estimated in BILOG-MG, Mplus and R (ltm). The accuracy of the item parameters and ability estimates were evaluated under six conditions that differed in the numbers of items and examinees. After looking at the resulting bias and root mean square error (RMSE) values, it can be concluded that Mplus is an unbiased program when compared to BILOG-MG and R (ltm). BILOG-MG can estimate parameters and standard errors close to the true values, when compared to Mplus and $\mathrm{R}$ (ltm).
\end{abstract}

Key Words: IRT, parameter estimation, Mplus, BILOG-MG, ltm

\section{INTRODUCTION}

In recent years, especially in the fields of education and psychology, item response theory (IRT) has been popular (Foley, 2010). Provision of the opportunity of modelling the relationship between examinees' ability and their response to an item, makes IRT models more preferable than classical test theory models (CTT) (de Ayala, 2009; Hambleton, Swaminathan, \& Rogers, 1991; Yen \& Fitzpatrick, 2006). CTT focuses on the number of correct answers given by the examinee in the test. In other words, two examinees with the same number of correct answers get the same score in terms of the measured property, regardless of whether the item is difficult or easy (Proctor, Teo, Hou \& Hsieh, 2005). Moreover, the major advantage of CTT is that it is easy to meet the assumptions in real test data (Fan, 1998; Hambleton \& Jones, 1993). On the other hand, IRT requires stronger assumptions than CTT (Crocker \& Algina, 1986). IRT is based on the probability of an examinee's ability to perform on any item according to his or her ability. IRT models are functions of items, characterized by item parameters, and the ability of the examinees. As its name implies, IRT models test the behavior at the item level. IRT models can be unidimensional or multidimensional. In this study, we considered only unidimensional IRT models. There are three item parameters used in unidimensional IRT models. These are difficulty, $b$; discrimination, $a$; and pseudo-guessing, $c$ parameters (Hambleton, Swaminathan \& Rogers, 1991; Van Der Linden \& Hambleton, 1997).

Unidimensional IRT models vary in the number of item parameters that are used. The one parameter logistic (1PL) model assumed that all items have an equal discrimination index and the probability of guessing an item correctly is zero. In the three parameter logistic (3PL) model all three item parameters vary across items. And in the two parameter logistic (2PL) model only the item difficulty and discrimination indices vary across items (Lord, 1980). The item response function for the two parameter logistic (2PL) model is defined as follows:

\footnotetext{
* This study was presented as oral presentation at $6^{\text {th }}$ International Congress on Measurement and Evaluation in Education and Psychology in KOSOVO.

** Dr, Mehmet Akif Ersoy University Faculty of Education, Burdur-Turkey, syuksel@ mehmetakif.edu.tr, ORCID ID: 00000002-8315-2637

*** Dr, Mehmet Akif Ersoy University Faculty of Education, Burdur-Turkey, nozturk@ mehmetakif.edu.tr, ORCID ID: 00000003-0179- 1986
}

To cite this article:

Uyar, Ş. \& Öztürk-Gübeş, N. (2020). The Importance of Sample Weights and Plausible Values in Large-Scale Assessments. Journal of Measurement and Evaluation in Education and Psychology, 11(1), 27-42. doi: 10.21031/epod.591415 


$$
P_{i}(\theta)=\frac{e^{D a_{i}\left(\theta-b_{i}\right)}}{1+e^{D a_{i}\left(\theta-b_{i}\right)}} \quad(\mathrm{i}=1,2, \ldots, \mathrm{n})
$$

where $P_{i}(\theta)$ is the probability that a randomly selected examinee with ability $\theta$ answers item i correctly. The parameter $b_{i}$ is referred to as index to item difficulty or threshold parameter and describes the point on the ability scale at which an examinee has a 50 percent probability of answering item i correctly. The discrimination parameter $a_{i}$ is propotional to the slope of $P_{i}(\theta)$ at point $\theta=b_{i}$. The constant $\mathrm{D}$ is a scaling factor that places the scale of the latent ability approximately on the standard normal metric when set to 1.7 (Hambleton \& Swaminathan, 1985).

One of the advantages of IRT is that item parameters can be estimated independent of the group and ability parameters can be estimated independent of the item (Hambleton, Swaminathan \& Rogers, 1991). For this reason, IRT provides an appealing conceptual framework for test development (Hambleton, 1989) and IRT-based item and ability estimations are frequently mentioned in test development studies. The aim of test development studies is to present the models which can estimate the most accurate and stable item and ability parameters. The estimation of parameters is important because the examinees' reported score based on these parameters can affect any decision about examinees. For this reason, researchers aim to reveal the most accurate model to estimate the parameters in various conditions (Rahman \& Chajewski, 2014).

In the literature, the effect of sample size and test length on parameter estimation is frequently investigated in IRT based test development studies. In these studies (Lim \& Drasgow, 1990; Lord, 1968; Öztürk-Gübeş, Paek \& Yao, 2018; Patsula \& Gessroli, 1995; Şahin \& Anı1, 2017; Yen, 1987; Yoes, 1995 ) although the minimum number of sample size and the exact length of the test cannot be certainly specified (Foley, 2010), the optimal number of sample size and test length which should be reached under various conditions can be revealed. The common point of these studies is that the number of sample size and test length should be particularly large in complex models and IRT models require large sample size to make accurate parameter estimations (Hambleton, 1989; Hulin, Lissak \& Drasgow, 1982).

Lord (1968) stated that, at least 50 items and 1000 sample sizes were required to estimate the discriminant parameter (a parameter) accurately for the 3PL model. Swaminathan and Gifford (1983) investigated the effect of sample size, test length, and the ability distribution on the estimation of item and ability parameters using the 3-PL model. Their results showed that the condition in which sample size was 1000 and test length was 20 produced more accurate estimates of the difficulty and guessing parameters, and fairly good estimates of the item discrimination parameters than the conditions in which sample size was 50 and test lengths were 10 or 15 and sample size was 200 and test lengths were 10 and 15. Hulin et al. (1982) suggested that at least 500 samples and 30 items were needed for the 2PL model. They also suggested that the number of sample size should be 1000 and the number of items should be 60 for the 3PL model or when sample size was 2000, test length should be 30. Also, for the 2PL model, Lim \& Drasgow (1990) suggested 750 as the sample size for 20 items; Şahin and Anıl (2017) suggested 500 as the sample size for 20 items and Gübeş, Paek and Yao (2018) pointed out that when the sample size was 500 or greater, estimation methods produced same and appropriate results with the test lengths of 11 (small), 22 (medium) or 44 (large).

In many test applications, it is not always possible to increase the sample size or test length. Therefore, in recent times researchers focus on the use of the most accurate model and computer program according to the sample size or test length. Baker (1987) stated that the parameter estimation and the computer program that is used constitute an inseparable whole. And the characteristics of the obtained parameters will be affected by the underlying mathematics of the program. For this reason, many computer programs are available at various times depending on the possibilities offered by technology. BILOGMG (Zimowski et al., 2003) has been widely used for parameter estimation in dichotomous items and has a long history (Baker, 1990; Lim \& Drasgow, 1990; Swaminathan \& Gifford, 1983). Recently, IRT analyses have been conducted using the libraries (e.g. package ltm, irtoys) in the open source program R (Rizopoulos, 2006, 2013; Bulut \& Zopluoğlu, 2013; Pan, 2012). Mplus (Muthén \& Muthén, 19982012) is another program that is preferred in analyzing latent models. Although there are a lot of programs for parameter estimation, they are questionable in terms of making accurate estimates. 
Therefore, simulation studies can be effective to evaluate the accuracy of estimations. Such studies allow researchers to compare the estimation results with the true values in various test conditions (Şahin \& Colvin, 2015).

Yen (1987), compared the performance of BILOG and LOGIST in terms of parameter estimates and item characteristic functions for the three-parameter logistic model. They used 1000 sample size with 10, 20 and 40 test lengths. They indicated that BILOG always produced more accurate estimates of item parameters especially in short tests. But they pointed out that two programs performed equally for the 20 and 40 item tests. Mislevy \& Stocking (1989) recommended using BILOG in short tests and/or small examinee samples, while LOGIST might be preferred in longer tests.

Şahin and Colvin (2015) investigated the accuracy of the item and ability parameters which were obtained from "ltm" R package. They compared item and ability estimates with the true parameters when test lengths were 20 and 40 and sample sizes were 250, 1000 and 2000. They considered bias, mean absolute deviation (MAD), and root mean square error (RMSE) for the evaluation of accuracy of "ltm package" in terms of parameter estimation. According to their findings, it can be concluded that accurate estimates with the 1PL, 2PL, and 3PL can be provided by using ltm. Especially to estimate $b$ parameters, $1 \mathrm{tm}$ produced more accurate results. Their findings showed that while $1 \mathrm{tm}$ estimated difficulty and ability parameters accurately there were some problems in guessing parameter (c) estimates. Results obtained from all the conditions showed that the accuracy of parameter estimation with ltm increased in all the three models as the number of examinees increased.

Rahman and Chahewski (2014) investigated the calibration results of 2PL and 3PL IRT models with 100 items and 1000 examinees in BILOG-MG, PARSCALE, IRTPPRO, flexMIRT, and R (ltm). They mentioned that $\mathrm{ltm}$ is the only software with a negative bias for the discrimination and guessing parameters while estimating the 3PL model. Their findings indicated that BILOG and PARSCALE underestimate item difficulties and latent traits, whereas IRTPRO and flexMIRT mostly overestimate them for 2PL models. And, R package ltm also showed negligible bias for item difficulty in 2 PL models. The package ltm is unable to perform with the other software programs in 3 PL models, but its recovery is precise for the latent trait using the 2PL model. Although there is some research about comparing performance of computer programs in IRT model parameter estimates, it is still necessary to conduct more research to compare the performance of different programs in parameter estimating.

The aim of this study is to investigate the effect of sample size and test length on the estimation of item parameters and their standard errors in 2PL models. Another aim of this study is to compare the performance of Mplus, BILOG-MG and R (ltm) in terms of parameter estimation in different sample sizes and test lengths. This study will contribute to the discussions about sufficient sample size or test length when studies are conducted based on IRT. On the other hand, the researchers will be able to get information about which of the programs they need to access in accordance with the available data or the parameters to be estimated. This research is original as it includes standart error comparison of parameters. The data which was simulated based on the parameters of a real test was used in the current study.

The basic problem investigated in the current study was "How do the parameters and their standard error estimates change in the BILOG-MG, Mplus and R (ltm) programs when the test length and sample size change?

\section{METHOD}

This research is a simulation based study examined the performance of different programs in terms of parameter estimation under specific conditions. 


\section{Data Generation}

The simulated data were used in this study. To mimic a real test situation, examinee responses were generated based on TIMSS 2015 mathematic test item parameters. The mean and standard deviation of item parameters which were used in data generation were given in Table 1.

Table 1. Item Parameters Means and Standard Deviations Obtained from TIMSS 2015 Application

\begin{tabular}{lccccccccc}
\hline & \multicolumn{3}{c}{ Test length $=\mathbf{3 0}$} & \multicolumn{5}{c}{ Test length = 60 } \\
\cline { 2 - 11 } & $\mathbf{a}$ & se (a) & $\mathbf{b}$ & se (b) & a & se (a) & b & se (b) \\
Mean & 1.22 & 0.09 & 0.70 & 0.05 & 1.24 & 0.09 & 0.66 & 0.05 \\
Std. dv. & 0.35 & 0.04 & 0.54 & 0.04 & 0.37 & 0.05 & 0.54 & 0.03 \\
\hline
\end{tabular}

Std. dv: Standart deviation

Furthermore, the ability parameters are drawn from a standard normal distribution which has mean zero and standard deviation one, $\mathrm{N} \sim(0,1)$. For the response of the $i$ th item and $n$th examinee; firstly, item response function was calculated based on 2PL model (see equation 1) then uniform random numbers were sampled from $(0,1)$. If the uniform random number was equal or less than the probability of correctly answering item, item was scored as 1 (correct). Otherwise, item $i$ was scored as 0 (incorrect).

In data simulation, test length and sample size were varied: sample sizes were 500, 1000 and 2000; test lengths were 30 and 60. In the current study, 3 sample sizes and 2 test lengths conditions yielded to generate six different data conditions. For each condition, 50 data sets were generated, which resulted in 300 generated response sets. Six simulation conditions are given in Table 2.

Table 2. Simulation Conditions

\begin{tabular}{ccc}
\hline Condition & Sample Size & Number of Items \\
\hline 1 & 500 & 30 \\
2 & 1000 & 30 \\
3 & 2000 & 30 \\
4 & 500 & 60 \\
5 & 1000 & 60 \\
6 & 2000 & 60 \\
\hline
\end{tabular}

\section{Data Analysis}

In the first step of the data analysis, item parameters were estimated by using the Maximum Likelihood Estimation (MLE) method according to 2PL model for each condition of test length and sample size. Parameters were estimated in BILOG-MG, Mplus and R (ltm). In all the programs, default settings were used.

Mplus is a statistical modeling program which has a flexible modeling capacity. Mplus allows researchers to do factor analysis, mixture modeling and structural equation modeling. In Mplus, categorical and continuous data that have single-level or multi-level structure can be analyzed. In addition, Mplus has extensive facilities for Monte Carlo simulation studies. Normally, non-normally distributed, missing or clustering data can be generated by using Mplus (Muthén \& Muthén, 1998, 2002, 2012).

$B I L O G-M G$ is a software program that is designed for analysis, scoring and maintenance of measurement instruments within the framework of IRT. The program is appropriate for the binary items scored right, wrong, omitted- or non-presented. The program is concerned with estimating the parameters of an item and the position of examinees on the underlying latent trait (Zimowski et al., 2003). 
Latent trait models which is shortly abbreviated as "ltm" is an open-source R software package. ltm can do analysis of univariate and multivariate dichotomous and polytomous data using latent trait models under the IRT. The package includes IRT models of Rasch, 2PL, 3PL, graded response and generalized partial credit (Rizopoulos, 2006). In the current study, analyses based on latent trait models were run under another R package, irtoys. The irtoys is a package which combined some useful IRT programs. These programs are ICL, BILOG-MG and $\mathrm{ltm}$. In the installing process of irtoys the ltm package is also automatically loaded (Partchev, 2017).

In the second step of the data analysis, the accuracy of item parameters was investigated by computing discrepancy between the estimate and true value of the parameter. In order to evaluate the recovery of item parameters and their standard errors, bias and root mean square error (RMSE) were calculated. Bias is defined as the average difference between true and estimated parameters. It is a measure of any systematic error in estimation. To obtain the average bias value, bias was calculated for each replication of each condition, and then an average bias for each condition was calculated. Bias can take both positive and negative values. When the bias value is zero and close to zero, it can be decided that the parameter estimation is unbiased. RMSE is a measure of precision that, like standard deviation, provides information about the average magnitude of parameter variation around the true parameter. RMSE always yields positive values and the minimum value of RMSE is zero. If the RMSE value obtained in the relevant condition is close to zero, it is decided that the estimation stability is high. As the RMSE value moves away from zero it is interpreted as low estimation stability. For a given parameter, bias and RMSE indexes were calculated as in equations 2 and 3:

$$
\begin{aligned}
\text { Bias } & =\left(\frac{1}{R}\right) \sum_{r=1}^{R} \hat{\varphi}_{r}-\varphi \\
R M S E & =\sqrt{\sum_{r=1}^{R}\left(\hat{\varphi}_{r}-\varphi\right)^{2} / R}
\end{aligned}
$$

where $\varphi$ is the parameter of interest and $r$ is the replication number index $(r=1,2, \ldots, R)$. In the item parameter recovery investigation, each of the data generating parameters is $\varphi$. These indices were averaged across all items to compute summary indices for a given condition.

\section{RESULTS}

The averages of RMSE and bias value for the estimated parameters in Mplus, BILOG-MG and R (with $1 \mathrm{tm})$ programs across the 50 runs are given in Table 3.

Table 3. RMSE and Bias Averages for Item Parameters and Standard Errors

\begin{tabular}{lcccccccc}
\hline & \multicolumn{3}{c}{ RMSE } & \multicolumn{4}{c}{ Bias } \\
\cline { 2 - 9 } & $\mathrm{b}$ & $\mathrm{se}(\mathrm{b})$ & $\mathrm{a}$ & $\mathrm{se}(\mathrm{a})$ & $\mathrm{b}$ & $\mathrm{Se}(\mathrm{b})$ & $\mathrm{a}$ & $\mathrm{se}(\mathrm{a})$ \\
\hline Mplus & 0,092 & 0,054 & 0,112 & 0,051 & 0,001 & 0,046 & 0,004 & 0,030 \\
BILOG-MG & 0,093 & 0,046 & 0,111 & 0,042 & 0,006 & 0,036 & $-0,012$ & 0,018 \\
R (ltm) & 0,109 & 0,056 & 0,121 & 0,044 & 0,023 & 0,047 & $-0,037$ & 0,019 \\
\hline
\end{tabular}

As seen in Table 1, while the $b$ parameter estimates of Mplus have the smallest average of RMSE values (0.092), $\mathrm{R}(\mathrm{ltm})$ estimates have the largest average (0.109). On the other hand, the standard error of $b$ parameter estimates of BILOG-MG program has the smallest RMSE average (0.046), and again R (ltm) estimates have the largest RMSE average (0.056). The slope (a) parameter estimates of BILOG-MG have the smallest RMSE average (0.111) and R (ltm) estimates have the largest value (0.121). Similarly, BILOG-MG program has the smallest RMSE average (0.042) for the standard error of a parameter but Mplus estimates have the largest values (0.051). 
Considering the bias values in Table 3, it can be said that the Mplus program has the smallest bias values for $a(0.004)$ and $b$ parameters (0.001); BILOG-MG has the smallest bias values for the $\operatorname{se}(b)(0.036)$ and $s e(a)(0.018)$ parameters. While, the $\mathrm{R}(\mathrm{ltm})$ has the largest mean of bias values for the $b(0.023)$, $s e(b)(0.047)$ and $a(-0.037)$ parameters; Mplus program has the largest bias values for the $s e(a)(0.030)$ parameter.

For each of the six conditions, the average of RMSE and bias values for the " $b$ " parameter over 50 replications are plotted in Figure 1.

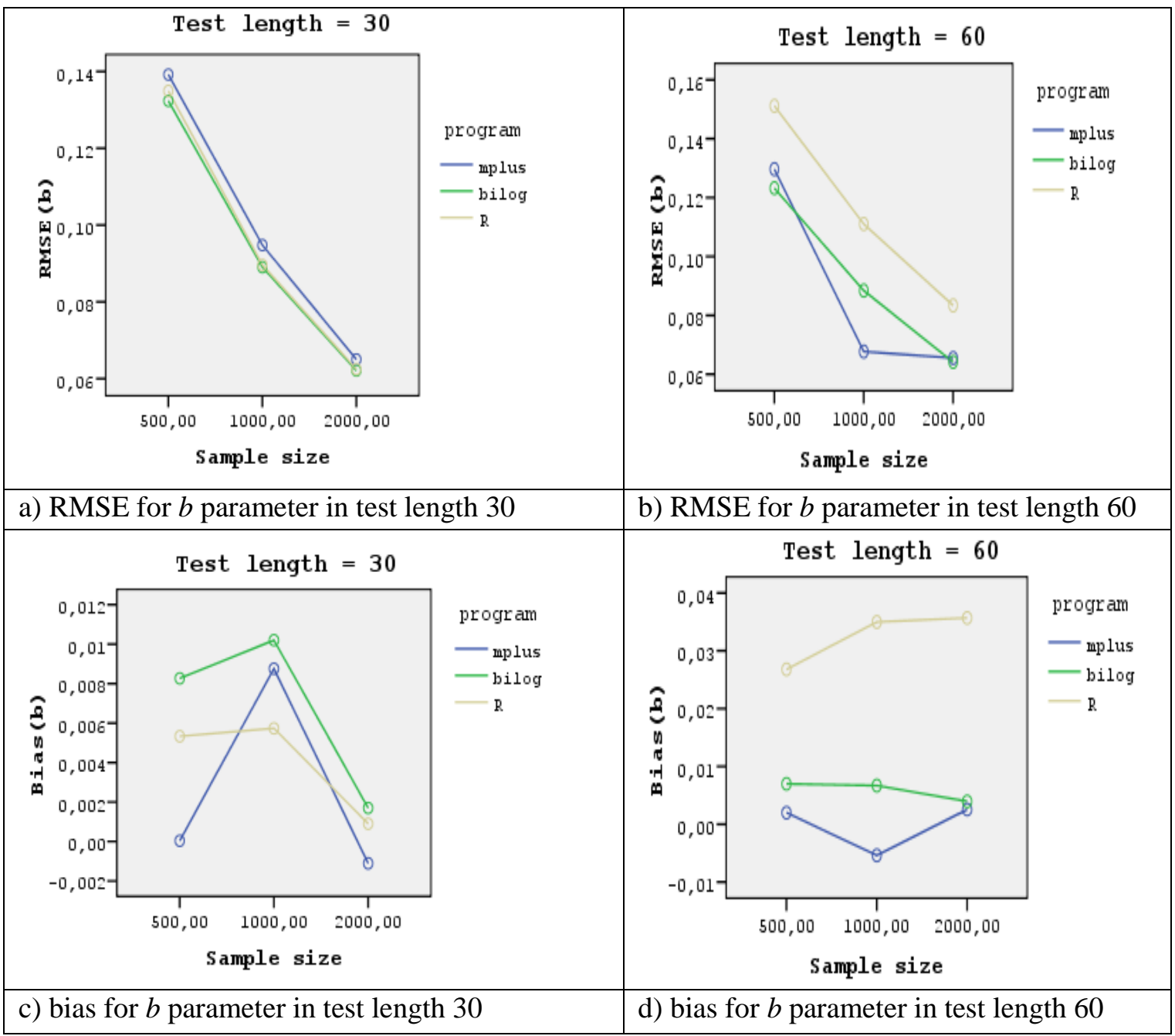

Figure 1. The Graphics for $b$ Parameter Based on RMSE and Bias

As seen in Figure 1a and Figure 1b where test lengths were 30 and 60, as sample size increased the RMSE values of $b$ parameter estimates decreased in all programs. When test length was 30 and sample size was 500, while BILOG-MG $b$ parameter estimates had the smallest RMSE values, Mplus had the largest ones. When sample size was 1000 , the $b$ parameter estimates of R and BILOG-MG programs had similar and smaller RMSE values than Mplus. When the sample size was 2000, although BILOG-MG and R (ltm) had similar and smaller RMSE values than Mplus, Mplus got very close RMSE values to other two programs (see Figure 1a).

When we consider RMSE values for the $b$ parameter at test length 60 in Figure $1 \mathrm{~b}$, we can say that BILOG-MG had the smallest and R (ltm) had the largest values. On the other hand, at the test length 1000, while Mplus had the smallest RMSE values, again R (ltm) had the largest values. When sample size was 2000, Mplus and BILOG-MG programs had similar and smaller RMSE values than R (ltm). 
We can say that in all sample sizes at the test length 60, based on RMSE index, R (ltm) performed worse than other programs in terms of estimating $b$ parameter.

The graphic in Figure 1c showed that at the test length 30, the smallest bias values for the $b$ parameter were obtained by Mplus and the largest ones were obtained by BILOG-MG program. However, at the sample size 1000, R (ltm) had the smallest bias values and again BILOG-MG had the largest RMSE values. At the sample size 2000, while Mplus had the smallest bias values, again BILOG-MG had very close but larger bias than $\mathrm{R}$ (ltm). Also, when sample size increased from 500 to 1000 , bias values of $b$ parameter estimates from all programs increased but as sample size increased from 1000 to 2000, bias values decreased (see Figure 1c).

If we consider bias values for the $b$ parameter at the test length of 60 and sample sizes of 500 and 1000 , while the smallest bias values were obtained by Mplus, the largest ones got from $\mathrm{R}$ program. At the sample size of" 2000 , bias values for b parameter estimates of $\mathrm{R}$ program were larger than other programs but BILOG-MG estimates had very close bias values to Mplus program (see Figure 1d).

For each of six conditions, the average of RMSE and bias values for the "se $(b)$ " parameter over 50 replications were plotted in Figure 2.

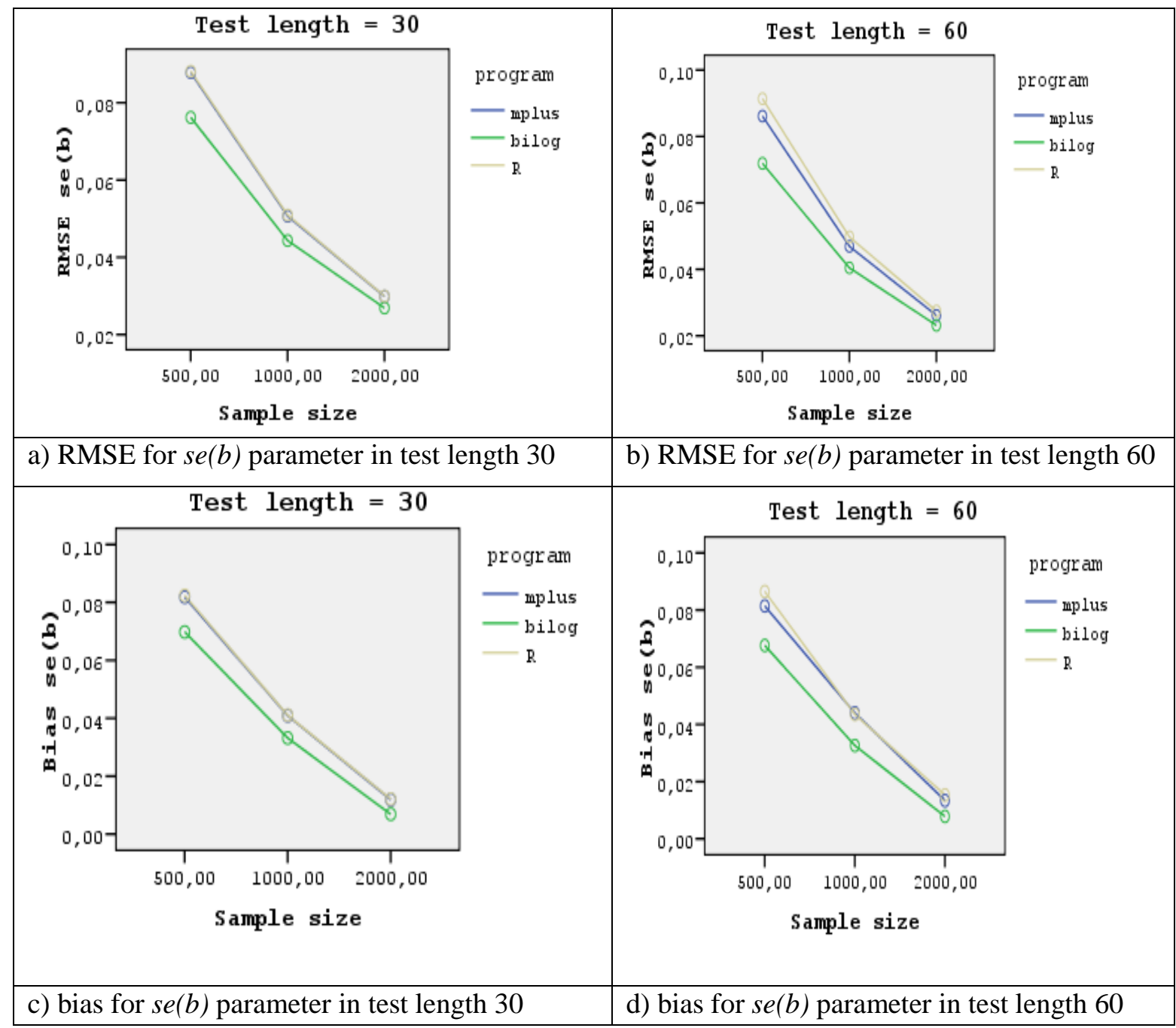

Figure 2. RMSE and Bias Values for $s e(b)$ Parameter

As seen in Figure 2, at the two test lengths as sample size increased, bias and RMSE values decreased for the $s e(b)$ estimates from all the programs. Considering the test length of 30 in Figure $2 \mathrm{a}$ and $2 \mathrm{~d}$, the 
smallest RMSE and bias values for the $s e(b)$ parameter were obtained from BILOG-MG estimates at all the sample sizes. And Mplus and $R(\mathrm{ltm})$ had similar but larger RMSE and bias values than BILOGMG. According to results, we can say that at all sample sizes, BILOG-MG program performed best in estimating $s e(b)$ parameter. Similarly, at the test length of 60 and sample size of 500, again BILOG-MG had the smallest and R (ltm) had the largest RMSE and bias values for the se(b) parameter (see Figure 2b). At the sample size of 1000 and 2000, Mplus and R (ltm) had similar but larger RMSE and bias values than BILOG-MG program. However, at the sample size of 2000, the performance of three programs got very close to each other, BILOG-MG still estimated smaller RMSE and bias values for the $s e(b)$ parameter. In other words, we can say that BILOG-MG performed best in terms of estimating $s e(b)$ parameter at all the test lengths and sample sizes.

For each of six conditions, the average of RMSE and bias values for the " $a$ " parameter over 50 replications are plotted in Figure 3.

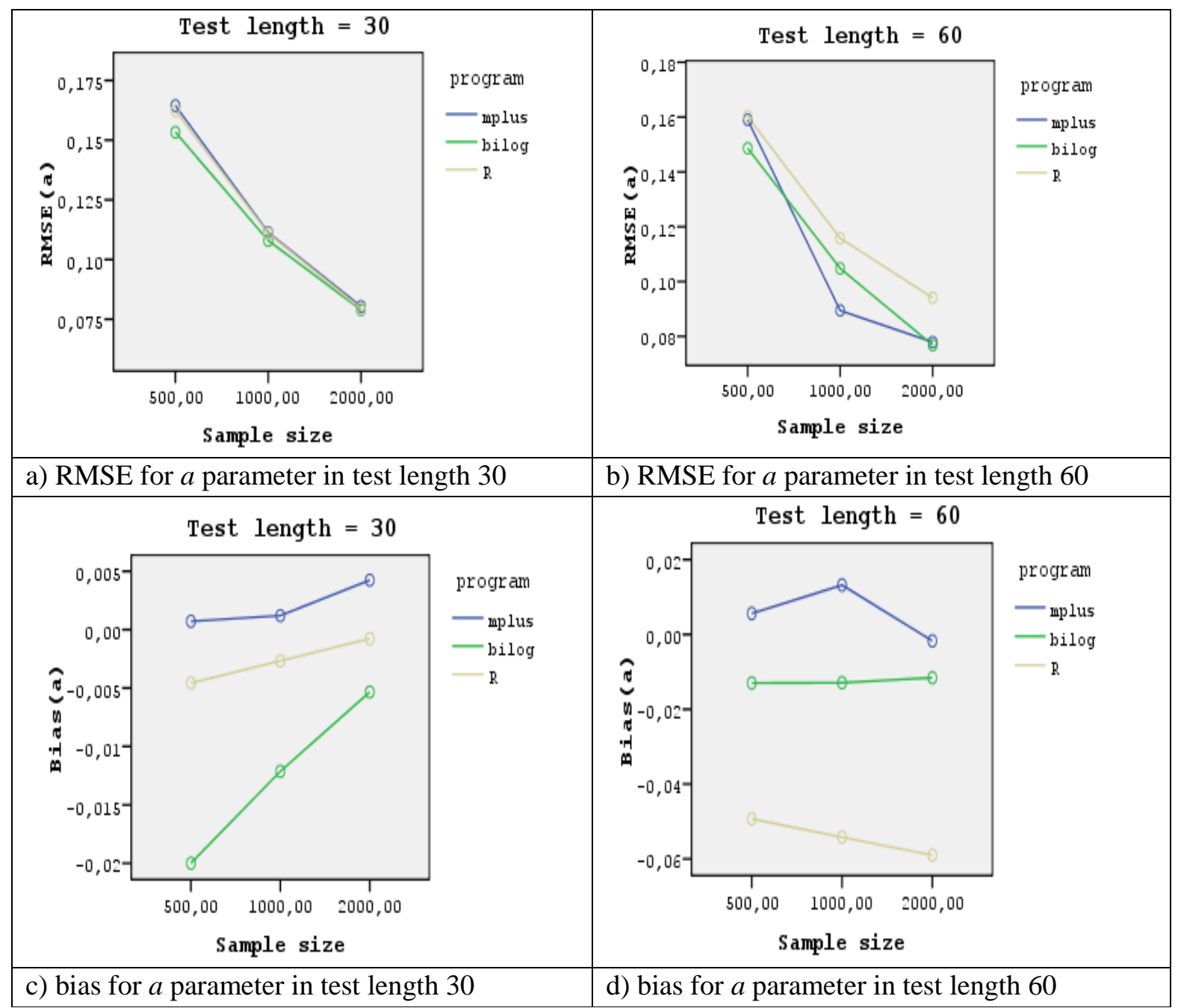

Figure 3. RMSE and Bias Values for $a$ Parameter

As shown in Figure 3a and 3b, when test lengths were 30 and 60, RMSE values of $a$ parameter decreased as the sample size increased. This drop was sharper for Mplus and BILOG-MG programs when the number of item was 60 . When test length was 30 and sample sizes were 500 and 1000, although BILOGMG program had smaller RMSE values than other programs, at the test length of 2000, all of the three programs had similar RMSE values (see Figure 3a). We can say that while BILOG-MG had the best 
performance at the sample size of 500 and 1000, at the sample size of 2000, all the programs performed similar in terms of estimating $a$ parameter.

When test length increased to 60, programs performance changed due to sample size. For example, at the sample size of 500, Mplus and R (ltm) performed similar but they had larger RMSE values than BILOG-MG estimates. Under the condition where the sample size was 1000, the Mplus program had smallest and the R (ltm) had the largest RMSE values. At the sample size of 2000, while Mplus and BILOG-MG performed best, R (ltm) performed worst (see Figure $3 \mathrm{~b}$ ).

As shown in Figure 3c, for the test length 30, as sample sizes increased, bias values decreased in all programs except for Mplus. Also, Mplus had the smallest bias values and BILOG-MG was the largest bias values at all sample sizes. At the test length of 60, although BILOG-MG performed as well as Mplus program, generally Mplus had the smallest and R (ltm) had the largest bias values at all the sample sizes.

In Figure 4, the average of RMSE and bias values for the "se(a)" parameter over 50 replications are plotted.

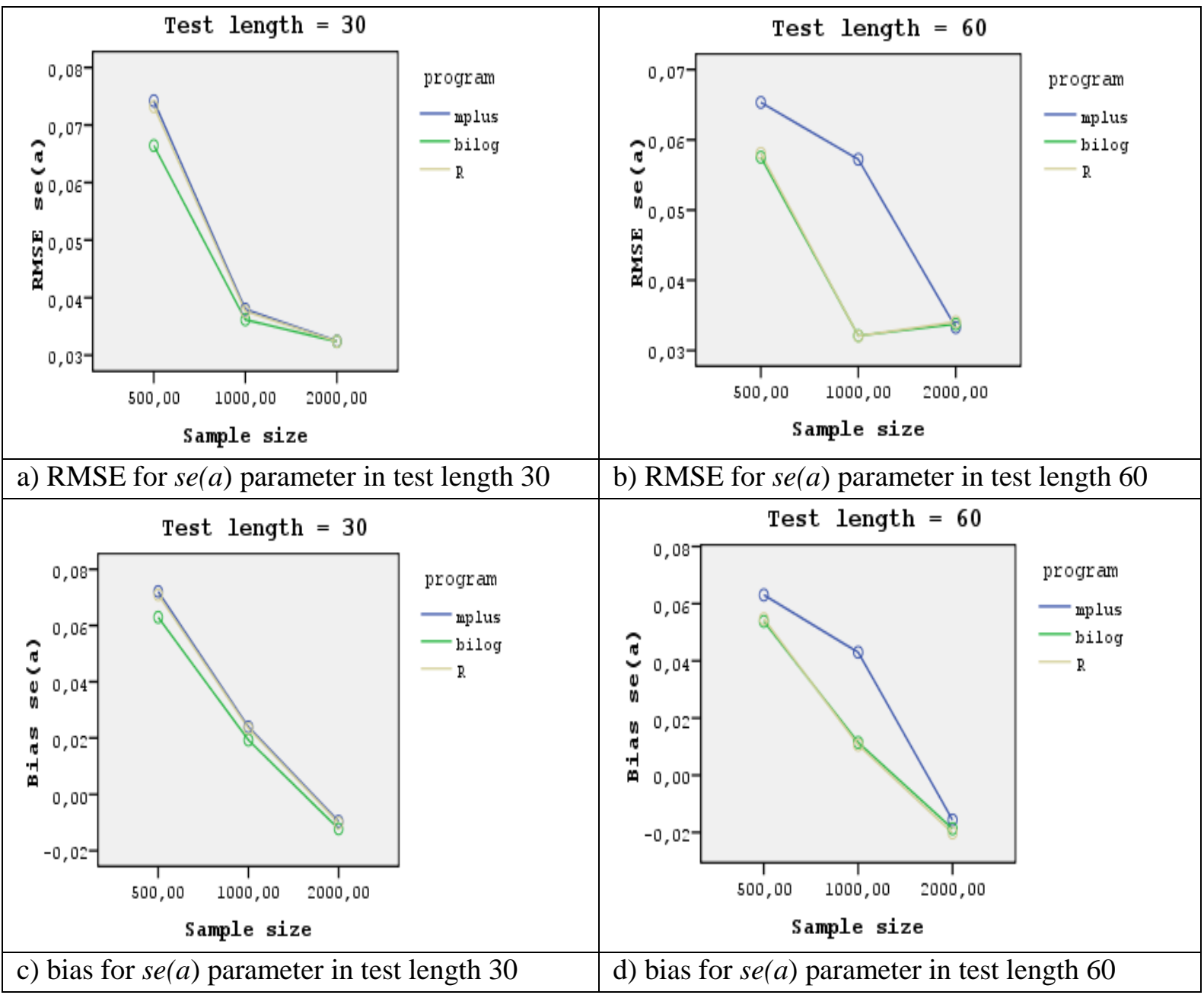

Figure 4. RMSE and Bias Values for se(a) Parameter

As seen in Figure 4a, in all the programs, as sample size increased, RMSE values of se(a) parameter decreased in test length 30 conditions. At the sample size of 500, while BILOG-MG had the smallest RMSE values and it had the best performance, Mplus and R (ltm) had similar but larger RMSE values. When the sample size increased from 500 to 1000 , RMSE values for $s e(a)$ were sharply decreased in all 
the programs and although BILOG-MG estimates of se(a) had the smallest RMSE values, we can say that all of the three programs showed similar performance. And especially at the sample size of 2000, the performance of three programs is the same (see Figure 4a).

In conditions where test length was 60 and samples sizes were 500 and 1000, R (ltm) and BILOG-MG had smillar and smaller RMSE values than Mplus, but at the sample size of 2000, all the programs had similar RMSE values (see Figure 4b). Also we can say that as sample size increased from 500 to 1000, the RMSE values decreased in all programs. When sample size increased from1000 to 2000, RMSE values decreased for Mplus, but for BILOG-MG and R (ltm), RMSE values increased (see Figure 4b).

When we looked at the bias values in Figures $4 \mathrm{c}$ and $4 \mathrm{~d}$, we can see that at the test lengths of 30 and 60, as sample size increased, bias values for se(a) decreased in all the programs. At the test length of 30 and sample sizes of 500 and 1000, Mplus and R (ltm) programs had similar but larger bias values than BILOG-MG program but at the test length of 60 still Mplus had the largest bias values, BILOG-MG and R (ltm) had similar and smaller values than Mplus. On the other hand, at the sample size of 2000, for both of test lengths, we can say that all the programs had similar bias values for se(a) estimates.

According to Table 3 and Figure 4, when the number of items was 30, the RMSE values of se (a) decreased as the sample size increased in all the programs. When the sample size was 500 , the smallest RMSE values were obtained by BILOG. All the programs showed similar performance when the sample size was 2000. When the number of item was 60, RMSE values of se (a) tended to decrease as the sample size increased. But when the sample size was 2000, the RMSE value of se (a) increased in BILOG and R (ltm) programs. The smallest RMSE values for se $(a)$ were obtained in BILOG-MG and $\mathrm{R}(\mathrm{ttm})$. In all the three programs, while the number of items were 30 and 60 , the bias values of se (a) decreased as the sample size increased. When test length was 30 , the smallest bias values were obtained by BILOG-MG. When the number of items was 60, BILOG-MG and R (ltm) showed better and similar performance compared to Mplus.

\section{DISCUSSION and CONCLUSION}

The aim of this study was to investigate the effects of sample size and test length on parameter estimates and to compare the performance of Mplus, BILOG-MG and R ( $1 \mathrm{tm})$ in terms of parameter estimation accuracy. The conclusions based on results can be listed as follows:

According overall results based on RMSE index, we can say that while Mplus was the best program in estimating $b$ parameter, it was the worst program in estimating se (a) parameter. BILOG-MG was the best and $\mathrm{R}(\mathrm{ltm})$ was the less effective in estimating $s e(b), a$ and $s e(a)$ parameters. This result is consistent with the findings of Rahman and Chajewski (2014). The researchers compared the RMSE values for the parameter estimates obtained by BILOG, PARSCALE, IRTPRO, flexMIRT and ltm package in $\mathrm{R}$ software. They found that although the estimation results were within acceptable ranges, the R (ltm) showed the most erroneous estimation. With regard to bias index, Mplus was the best in estimating $b$ and $a$ parameters but it was the worst program in estimating $s e(a)$ parameter. On the other hand BILOG-MG was the best in estimating $s e(a)$ and $s e(b)$ parameters. Lastly, R (ltm) was the worst in estimating, $b$, se(b) and $a$ parameters. Besides, Muthén (1999) noted that small differences between BILOG-MG and Mplus estimates can be ignored, because both programs use the ML estimation but BILOG uses the logit function $(D=1.7)$ instead of the probit function.

In all test the lengths, as sample sizes increased, RMSE values decreased for all the parameter estimates. This finding supports the conclusion that the increasing sample size minimizes RMSE values for parameter estimation in the literature (Şahin \& Anıl, 2017; Şahin \& Colvin, 2015; Lord,1968; Ree \& Jensen,1980). The consistency of the estimator increases as the sample size increases, and estimated parameters tend to approach to the true values (Thissen \& Wainer, 1982). In addition, as the sample size increases, the standard errors of the sample decrease, therefore, RMSE values for parameter estimations can be reduced (Stone, 1992). As stated by Edelen and Reeve (2007), the standard errors of parameter estimations are also reduced as the sample size increases. 
Based on RMSE index, at the test length of 30 and sample size of 500, BILOG-MG was the best performing program in estimating $b$ parameter but as sample size increased to 1000 or to $2000, \mathrm{R}$ (ltm) performed as well as BILOG-MG. According to Şahin \& Colvin (2015), especially $b$ parameters can be estimated most accurately by $\mathrm{ltm}$ for $1 \mathrm{PL}, 2 \mathrm{PL}$ and 3PL models. In our study, although the performance of Mplus was found to be closer to the other programs at sample size of 2000, generally it was the worst performing program in estimating $b$ parameter. When test length increased to 60 , at all of the sample sizes, $\mathrm{R}(\mathrm{ltm})$ was the less effective program in estimating $b$ parameter and the performance of BILOGMG and Mplus program was affected by the sample sizes. For example, while BILOG-MG performed better than Mplus at the sample size 500, Mplus performed better at sample size 1000 and both programs performed similar at the sample size of 2000.

In terms of bias index at the test length of 30 , while Mplus was the best performing at sample sizes of 500 and 2000, R (1tm) was the best at sample size of 1000 and BILOG-MG was the low performing program in estimating $b$ parameter. When test length was increased to 60 , although the performance of BILOG-MG got very close to that of Mplus program at the sample size of 2000, Mplus was the best and $\mathrm{R}(\mathrm{ltm})$ was the worst performing program in estimating $b$ parameter.

Another conclusion that can be drawn from this study according to RMSE and bias index for $s e(b)$ is that, BILOG-MG was the best performing program at all the test lengths and sample sizes. Although at the test length of 60, Mplus performed better than R (ltm) in some cases (i.e.at sample size 500), generally Mplus and R (ltm) showed similar performance. And another result is that as sample size increased, bias in estimating $s e(b)$ parameter decreased in all the programs. According to Toland (2008), the accuracy of the estimated $s e(b)$ in BILOG- MG is related to sample size for 2 PL model. He found that for sample size of 4000 , consistent estimation of $s e(b)$ can be found throughout the range of difficulty parameters. But when sample size was 500, accuracy of $s e(b)$ decreased for larger $b$ parameters in BILOG-MG. So he suggests that researchers can use BILOG-MG confidently for se $(b)$ estimations in other applications with large sample sizes.

If we consider RMSE values for the $a$ parameter, especially at the smallest sample sizes and for both test lengths, BILOG-MG was the best performing program. For the test length 30 , at the sample sizes of 1000 and 2000, the performance of three the programs was very similar. At the test length of 60, although Mplus was the best performing program at sample size of 1000, BILOG-MG caught Mplus at sample size of 2000. Lastly, we can say that R (ltm) was the low performing program for test length 60.

In terms of bias values for $a$ parameter, results showed that at the test length 30, Mplus was the best and BILOG-MG was the worst performed. At the test length 60, although BILOG-MG performed as well as Mplus program, generally Mplus performed best and $\mathrm{R}(\mathrm{ltm})$ performed the worst.

For se (a) parameter, based on RMSE index, at the test length 30, although R (ltm) and Mplus programs caught BILOG-MG's performance at sample sizes 1000 and 2000, generally BILOG-MG was the best. On the other hand, for the test length 60, although the three programs performed similar at the biggest sample size, BILOG-MG and R (ltm) performed similar and better than Mplus. According to Toland (2008), users of BILOG-MG can get reasonably accurate estimates of $s e(a)$ under the 2PL model for smaller values of $a$ parameters (i.e., a $<1.4$ ). These findings concur with the findings of the current study. This may be due to the fact that the true values of $a$ parameter are less than 1.4 for only 4 items within 30 items and less than 1.4 for 13 items within 60 items.

In the previous studies, it is seen that RMSE values obtained for $a$ parameter were between 0.11 and 0.15 and between 0.10 to 0.14 for $b$ parameter. In this study, the RMSE values obtained from Mplus, BILOG-MG and R (ltm) were consistent with the previous studies, because they are in the same range as those obtained in previous studies (Gao \& Chen, 2005; Kim, 2006; Yen, 1987). Therefore, it can be said that all the three programs can be used to estimate $a$ and $b$ parameters, because they predict $a$ and $b$ parameters close to their true values. 


\section{REFERENCES}

Baker, F. B. (1987). Methodology review: Item parameter estimation under the one, two and three parameter logistic models. Applied Psychological Measurement, 11(2), 111- 141.

Baker, F. B. (1990). Some observations on the metric of BILOG results. Applied Psychological Measurement, 14(2), 139-150. DOI: https://doi.org/10.1177/014662169001400203

Baker, F. B. (1998). An investigation of the item parameter recovery of a Gibbs sampling procedure. Applied Psychological Measurement, 22(2), 153-169. DOI: https://doi.org/10.1177/01466216980222005

Bulut, O. \& Zopluoğlu, C. (2013). Item parameter recovery of the graded response model using the $R$ package ltm: A Monte Carlo simulation study. Paper presented at the annual meeting of the American Educational Research Association, San Francisco, CA.

Crocker, L. \& Algina, J. (1986). Introduction to classical and modern test theory. N.Y: CBS College Publishing Company.

de Ayala, R. J. (2009). The theory and practice of item response theory. New York: The Guilford Press.

Edelen, M. O., \& Reeve, B. B. (2007). Applying item response theory (IRT) modeling to questionnaire development, evaluation, and refinement. Quality of Life Research, 16(1), 5-18. DOI: http://dx.doi.org/10.1007/s11136-007-9198-0

Fan, X. (1998). Item response theory and classical test theory: An empirical comparison of their item/person statistics. Educational and Psychological Measurement, 58(3), 357-381. DOI: https://doi.org/10.1177/0013164498058003001

Foley, B. (2010). Improving IRT parameter estimates with small sample sizes: Evaluating the efficacy of a new data augmentation technique. Open Access Theses and Dissertations from the College of Education and Human Sciences. Paper 75

Gao, F. \& Chen, L. (2005). Bayesian or non-Bayesian: A comparison study of item parameter estimation in the three-parameter logistic model. Applied Measurement in Education, 18(4), 351-380.

Gübeş, N. Ö., Paek, I., \& Cui, M. (2018). Örneklem büyüklüğünün ve test uzunluğunun MTK parametre kestirimine etkisi. Pegem Atıf İndeksi, 135-148.

Hambleton, R. K. (1989). Principles and selected applications of item response theory. In R. Linn (Ed.), Educational Measurment (3rd.ed., pp. 147-200). New York: Macmillan.

Hambleton, R. K., \& Jones, R. W. (1993). Comparison of classical test theory and item response theory and their applications to test development. Educational Measurement: Issues and Practice, 12(3), 38-47. DOI: https://doi.org/10.1111/j.1745-3992.1993.tb00543.x

Hambleton, R. K. \& Swaminathan, H. (1985). Item response theory principles and applications. Boston: KluwerNijhoff Publishing

Hambleton, R. K., Swaminathan, H. \& Rogers, H. J. (1991). Fundamentals of item response theory. Newbury Park, Calif.: Sage Publications.

Hulin, C. L., Lissak, R. I., \& Drasgow, F. (1982). Recovery of two and three-parameter logistic item characteristic curves: A Monte Carlo study. Applied Psychological Measurement, 6(3), 249-260. http://dx.doi.org/ $10.1177 / 014662168200600301$

Kim, S. (2006). A comparative study of IRT fixed parameter calibration methods. Journal of Educational Measurement, 43(4), 355-381. DOI: https://doi.org/10.1111/j.1745-3984.2006.00021.x

Lim, R. G. \& Drasgow, F. (1990). Evaluation of two methods for estimating item response theory parameters when assessing differential item function. Journal of Applied Psychology, 75(2), 164-174.

Lord, F. M. (1968). An Analysis of the Verbal Scholastic Aptitude Test using Birnbaum's three-parameter logistic model. Educational and Psychological Measurement, 28(2), 989-1020. DOI: https://doi.org/10.1002/j.2333-8504.1967.tb00987.x

Lord, F. M. (1980). Applications of item response theory to practical testing problems. Hillsdale, NJ: Lawrence Erlbaum.

Mislevy, R. J. \& Stocking, M. L. (1989). A consumer's guide to LOGIST and BILOG. Applied Psychological Measurement, 13(1), 57-75.

Muthén, B. O. (1999). IRT models in Mplus. Retrieved from http://www.statmodel.com/discussion/messages/23/25.html

Muthén, L. K., \& Muthén, B. O. (1998-2012). Mplus user's guide (8th ed.). Los Angeles, CA: Muthén \& Muthén

Muthén, L. K., \& Muthén, B. O. (2002). How To Use A Monte Carlo Study To Decide On Sample Size and Determine Power. Structural Equation Modeling: A Multidisciplinary Journal, 9(4), 599-620.

Pan, T. (2012). Comparison of four maximum likelihood methods in estimating the Rasch model. Paper presented at the annual meeting of the American Educational Research Association, Vancouver, Canada.

Partchev, I. (2017). Package 'irtoys'. A collection of functions related to item response theory (IRT). 
Uyar, Ş., Öztürk-Gübeş, N. / Item Parameter Estimation for Dichotomous Items Based on Item Response Theory: Comparison of BILOG-MG, Mplus and R (Itm)

Patsula, L. N., \& Gessaroli, M. E. (1995). A comparison of item parameter estimates and ICCs produced with TESTGRAF and BILOG under different test lengths and sample sizes. Paper presented at the annual meeting of the National Council on Measurement in Education, San Francisco, CA.

Proctor, T., Teo, K.-S., Hou \& J., Hsieh (2005). Comparison of Parameter Recovery in a 2 Parameter Logistic Item Response Model using MLE and Bayesian MCMC Methods. Class project for 07P:148/22S:138 Bayesian Statistics, University of Iowa.

Rahman, N. \& Chajewski, M. (2014). A Comparison and Validation of 2- and 3-PL IRT Calibrations in BILOG, PARSCALE, IRTPPRO, flexMIRT, and LTM (R). National Council of Measurement in Education at Philadephia.

Ree, M. J., \& Jensen, H. E. (1980). Effects of sample size on linear equating of item characteristic curve parameters. In D. J. Weiss (Ed.), Proceedings of the 1979 Computerized Adaptive Testing Conference. Minneapolis, MN: University of Minnesota.

Rizopoulos, D. (2006). ltm: An R package for latent variable modelling and item response theory analyses. Journal of Statistical Software, 17(5), 1-25.

Swaminathan, H. \& Gifford, J. (1983). Estimation of parameters in the three-parameter latent trait model. In D. J. Weiss \& R. D. Bock (Eds.), New horizons in testing: latent trait test theory and computerized adaptive testing (pp. 13-30). New York: Academic Press.

Stone, C. A. (1992). Recovery of marginal maximum likelihood estimates in the two-parameter logistic response model: An evaluation of MULTILOG. Applied Psychological Measurement, 16(1), 1-16. DOI: http://dx.doi.org/10.1177/014662169201600101

Sahin, A., \& Anıl, D. (2017). The effects of test length and sample size on item parameters in item response theory. Educational Sciences: Theory and Practice, 17(1), 321-335. DOI: 10.12738/estp.2017.1.0270

Şahin, F. \& Colvin, K. (2015). Evaluation of R package ltm with IRT dichotomous models. NERA Conference Proceedings, 6.

Thissen, D. \& Wainer, H. (1982). Some standard errors in item response theory. Psychometrika, 47(4), $397-412$. DOI: $10.1007 / \mathrm{BF} 02293705$

Toland, M. D. (2008). Determining the accuracy of item parameter standart error of estimates in BILOG-MG3. Doctoral dissertation. Available from ProQuest LLC (UMI Number 3317288)

Van der Linden, W. \& Hambleton, R. K. (1997). Handbook of modern item response theory. Newyork: SpringerVerlag.

Yen, W. M. (1987). A comparison of the efficiency and accuracy of BILOG and LOGIST. Psychometrika, 52(2), 275-291. DOI: http://dx.doi.org/10.1007/BF02294241

Yen, W., \& Fitzpatrick, A. R. (2006). Item response theory. In R. L. Brennan (Ed.), Educational measurement (4th ed., pp. 111-153). Westport, CT: Praeger Publishers.

Yoes, M. (1995). An updated comparison of micro-computer based item parameter estimation procedures used with the 3-parameter IRT model. Saint Paul, MN: Assessment Systems Corporation.

Zimowski, M., Muraki, E., Mislevy, R. J., \& Bock, R. D. (2003). BILOG-MG 3: Item analysis and test scoring with binary logistic models. Chicago, IL: Scientific Software.

\section{İki Kategorili Puanlanan Maddelerde Madde Tepki Kuramına Dayalı Parametre Kestirimi: BILOG-MG, Mplus and R (ltm) Karşılaş̧tırması}

\section{Giriş}

Son yıllarda özellikle eğitim ve psikoloji alanlarında madde tepki kuramı (MTK) modellerinin kullanımı popülarite kazanmıştır (Foley, 2010). MTK'nın bireyin yeteneği ile maddeye verdiği yanıt arasındaki ilişkiyi modelleyebilme avantajı sunması klasik test kuramı (KTK) modellerine göre daha çok tercih edilmesini sağlamıştır (de Ayala, 2009; Hambleton, Swaminathan \& Rogers, 1991; Yen \& Fitzpatrick, 2006). KTK, bireyin testte verdiği doğru cevap sayısına odaklanmaktadır. Yani doğru cevap sayısı aynı olan iki birey sorunun zor ya da kolay olması dikkate alınmadan ölçülen özellik bakımından aynı puana sahip olmaktadır (Proctor, Teo, Hou \& Hsieh, 2005 ). Oysa MTK, bireyin yeteneğine göre herhangi bir madde üzerinde göstereceği performansın olasılığı üzerine temellenmektedir ve madde parametrelerini gruptan bağımsız, yetenek parametrelerini ise maddeden bağımsız olarak kestirmektedir (Hambleton, 
Swaminathan \& Rogers, 1991). Bu nedenle MTK' ya dayalı madde ya da yetenek kestirimleri özellikle test geliştirme çalışmalarında adından sıklıkla söz ettirmektedir.

Test geliştirme çalışmalarında madde ve yetenek parametrelerini en doğru ve stabil şekilde kestirebilen modellerin ortaya konulması amaçlanmaktadır. Çünkü bireyin rapor edilen puanı, hakkında alınabilecek herhangi bir kararı etkileyebilmektedir. Bu nedenle araştırmacılar çeşitli koşullarda en doğru kestirim yapan modeli ortaya koymayı amaçlamaktadır (Rahman \& Chajewski, 2014). Alan yazında MTK' ya dayalı test geliştirme çalışmalarında örneklem büyüklüğü ve test uzunluğunun parametre kestirimlerine olan etkisi sıklıkla araştırılan konu olarak ele alınmaktadır. MTK modelleri doğru parametre kestirimleri yapabilmek için büyük örneklemlere ihtiyaç duymaktadır (Hambleton, 1989; Hulin, Lissak \& Drasgow, 1982). Her ne kadar minimum örneklem sayısı ve test uzunluğunun ne olması gerektiği konusunda kesin kurallar koyulamasa da (Foley, 2010) yapılan çalışmalar çeşitli koşullarda ulaşılması gereken örneklem sayısını ortaya koymaya yöneliktir (Lord, 1980; Patsula \& Gessaroli, 1995; Yen, 1987; Yoes, 1995). Çalışmaların ortak noktası aslında örneklem sayısı ve test uzunluğunun özellikle karmaşık modellerde büyük olmas1 gerektiği yönündedir.

Lord (1968) güçlük, ayırt edicilik ve şans parametrelerinin kestirildiği 3 parametreli lojistik modelde ayırt edicilik parametresini doğru kestirebilmek için en az 50 madde ve 1000 örneklem büyüklüğü gerektiğini belirtmiştir. Hulin ve diğerleri (1982) 200, 500, 1000 ve 2000 örneklem sayıları ile 15, 30 ve 60 sayıda maddeden oluşan test uzunluklarını dikkate alarak 2PL ve 3PL modele göre kestirimler yapmıştır. İki parametreli lojistik model için en az 500 örneklem ve 30 madde ayısına ihtiyaç duyulacağını belirtmiştir. Ayrıca 3PL model için örneklem sayısının 1000, madde sayısının ise 60 olmasını önermiştir. Ancak örneklem sayısı 2000, madde sayısı 30 olduğunda da çok benzer kestirim sonuçları elde etmiştir. Bu nedenle örneklem sayısının arttırılamadığı durumda madde sayısını artırmak bir yol olarak tercih edilebilmektedir.

Ancak, birçok test uygulamasında örneklem büyüklüğünü ya da test uzunluğunu arttırmak çok mümkün değildir. Bu nedenle çalışmalar artık örneklem büyüklüğü ya da test uzunluğuna göre en doğru modelin ve bilgisayar programının kullanımına yoğunlaşmaktadır. Baker (1987), parametre kestirimi ve kullanılan bilgisayar programının ayrılmaz bir bütün oluşturduğunu ve elde edilen madde parametre karakteristiklerinin programın altında yatan matematikten etkileneceğini belirtmiştir. Bu nedenle çeşitli zamanlarda teknolojinin sunduğu imkânlara bağlı olarak birçok bilgisayar programı kullanıma sunulmuştur. BILOG-MG (Zimowski, Muraki, Mislevy \& Bock, 2003) iki kategorili maddelerde parametre kestirimi için yaygın bir şekilde kullanılan ve uzun geçmişe sahip olan programdır (Baker, 1990; Lim \& Drasgow, 1990; Swaminathan \& Gifford, 1983). Son zamanlarda MTK analizlerinin, açık kaynaklı program olan R programı (Rizopoulos, 2006, 2013) içerisindeki paketler (e.g. package ltm, irtoys) kullanılarak yürütüldüğüne rastlanmaktadır (Bulut \& Zopluoğlu, 2013; Pan, 2012). R programı ücretsiz olduğu için yaygın şekilde kullanılmaktadır. Yine birçok analizi yapma imkânı sunan ve ücretli bir program olan Mplus (Muthén \& Muthén, 1998-2012) son zamanlarda adından sıklıkla söz ettirmektedir ve örtük modelleri ortaya koymada tercih edilmektedir.

$\mathrm{Bu}$ bilgiler dikkate alındığında test uzunluğu ve örneklem büyüklüğ̈̈ne ilişkin araştırmalara yer verilmesi gerektiği ve program türlerine göre elde edilen sonuçlarının karşılaştırılmasına ihtiyaç olduğu düşünülmektedir. Bu çalışma sözü geçen örneklem büyüklüğü ve test uzunluğu faktörlerinin MTK'nın 2PL modellerinde madde parametreleri ve madde kestirimlerine ait standart hata değerleri üzerine etkisinin araştırılması amacını taşımaktadır. Araştırmanın bir diğer amacı ise bu koşullar altında, alanyazında bu üçünün karşılaştırılmasına rastlanmadığ için, Mplus, BILOG ve R (ltm) programlarının parametre kestirimindeki performanslarını karşılaştırmaktır. Bu yönüyle ilgili araştırma MTK temel alınarak yapılan çalışmalarda yeterli örneklem büyüklügünün ya da madde sayısının ne olması gerektiği konusundaki tartışmalara önemli katkıları olacağı düşünülmektedir. Öte yandan araştırmacılara eldeki verilere ya da kestirilecek parametrelere uygun olarak programlardan hangilerine ulaşmaları gerektiği konusunda fikir verebilecektir. Araştırma, parametrelere ilişkin standart hataları da karşılaştırmaya dâhil etmesi bakımından orijinallik özelliğini sağlamaktadır. Araştırmada simülasyon verileri kullanılmış ancak, veriler gerçek bir sınavdan kestirilen parametrelere uygun olarak üretilmiştir. Bu nedenle simülasyon sonuçları önceki çalışmalarla kıyaslanabilecek niteliktedir (Hulin ve diğerleri, 1982; Yen, 1987; Baker, 1998; Gao \& Chen, 2005; Thissen \& Wainer, 1982). 
Tüm bunlar dikkate alındığında araştırmada ele alınan temel problem test uzunluğu ve örneklem büyüklüğü değiştiğinde parametre ve bunlara ait standart hata kestirimleri BILOG, Mplus ve R (ltm) programlarında nasıl değişmektedir? şeklinde belirlenmiştir.

\section{Yöntem}

$\mathrm{Bu}$ çalışmada kullanılan veriler R programında yetenek parametreleri aritmetik ortalaması 0 , standart sapmas1 1 olan standart normal dağılım gösterecek şekilde üretilmiştir. TIMSS 2015 matematik uygulamasından hesaplanan madde parametreleri bu çalışmada verileri üretmek amacıyla kullanılmıştır.

Çalışmada örneklem büyüklüğü ve test uzunluğu simülasyon koşulları olarak ele alınmıştır. Örneklem büyüklüğü 500,1000 ve 2000 test uzunluğu ise 30 ve 60 olacak şekilde 6 farklı koşul 50 tekrar yapılarak karşılaştırılmıştır. Bu çalışmada madde parametreleri 2 PL modele göre En Çok Olabilirlik Yöntemi (Maximum Likelihood Estimation-MLE) kestirim yöntemi kullanılarak elde edilmiştir. Veriler BILOGMG, Mplus programlarında ve R programında irtoys paketinde ltm ile kestirilmiştir. Güçlük ve eğim (ayırt edicilik) parametreleri ve bunlara ait standart hataları (sh) karşılaştırmak amacıyla RMSE ve yanlılık indeksleri hesaplanmıştır.

\section{Sonuç ve Tartışma}

$\mathrm{Bu}$ araştırmanın amacı örneklem büyüklüğü ve test uzunluğunun parametre kestirimi üzerindeki etkisini incelemek ve Mplus, BILOG-MG ve R (ltm) programlarının parametre kestirimindeki performanslarını karşılaştırmaktır.

Araştırmadan elde edilen RMSE indeksleri dikkate alındığında Mplus programının $b$ parametresini kestirmede en iyi, sh (a) parametresini kestirmede en düşük performansı sergilediği görülmüştür. BILOG-MG $s h(b), a$ ve $s h(a)$ parametrelerini en iyi kestiren program iken R (ltm) bu parametreleri kestirmede en düşük performansı sergilemiştir. Bu sonuç Rahman \& Chajewski (2014)'ün bulgularıyla tutarlılık göstermektedir. Araştırmacılar BILOG, PARSCALE, IRTPRO, flexMIRT ve ltm (R) ile kestirdikleri parametrelere ilişkin RMSE değerlerini karşılaştırdıklarında kabul edilebilir derecede olsa da en hatalı kestirimin ltm programında olduğunu göstermişlerdir. Yanlılık indekslerine bakıldığında $b$ ve $a$ parametrelerini en yansız kestiren programın Mplus olduğu görülmüștür. Ancak bu program $s h(a)$ parametresini en yanlı kestiren programdir. BILOG-MG program $1 s h(a)$ ve $s h(b)$ parametresini en yansiz kestiren program olmuştur. $\mathrm{R}(\mathrm{ltm})$ ise $b, \operatorname{sh}(b)$ ve $a$ parametresini en yanlı kestiren programdır. Muthén'e (1999) göre, BILOG ve Mplus kestirimleri arasındaki küçük farklar göz ardı edilebilmektedir, çünkü her iki program da ML kestirim yöntemini, ancak BILOG programı probit fonksiyon yerine logit fonksiyonu $(\mathrm{D}=1.7)$ kullanmaktadır.

Araştırma bulguları tüm programlarda örneklem büyüklüğü arttıkça $a$ ve $b$ parametreleri ile bu parametrelerin standart hatalarına ilişkin kestirilen RMSE değerlerinin genel olarak düştüğünü göstermiştir. Bu bulgu alan yazında örneklem büyüklüğünün parametre kestirimine ilişkin RMSE değerlerini küçülttüğü sonucunu destekler niteliktedir (Şahin \& Anıl, 2017; Şahin \& Colvin, 2015; Lord,1968; Ree \& Jensen,1980). Örneklem büyüklüğü arttıkça, kestiricinin tutarlılığı artmakta ve gerçek parametre değerine daha yakın kestirimler elde edilmektedir (Thissen \& Wainer, 1982). Ayrıca, örneklem büyüklüğü arttıkça örneklem dağılımına ilişkin standart hatalar azalmakta dolayısıyla parametre kestirimlerine ilişkin RMSE değerleri azalmaktadır (Stone, 1992). Edelen \& Reeve (2007)'nin de belirttiği gibi örneklem büyüklüğü arttıkça parametre kestirimlerine ait standart hatalar da küçülmektedir.

RMSE indekslerine göre test uzunluğu 30 ve örneklem büyüklüğü 500 olduğunda BILOG-MG programının $b$ parametresini en iyi kestirdiği, ancak örneklem büyüklüğ̈̈ 1000 ve 2000 olduğunda $\mathrm{R}$ (ltm) ile BILOG-MG'den daha iyi kestirimler elde edildiği görülmüştür. Şahin \& Colvin (2015) de 1 PL, 2PL ve 3PL modellerde ltm paketinin $b$ parametresini en doğru kestirdiğini belirtmiştir. 
Bu çalışmada Mplus programının 2000 örneklem büyüklügünde $b$ parametresi için diğer programlara yakın kestirim sonuçları elde ettiği görülse de genel olarak $b$ parametresini 30 madde sayısı ve 2000 örneklem büyüklügünde en kötü kestirdiği sonucuna varılmıştır. Test uzunluğu 60 olduğunda tüm örneklem büyüklüklerinde $\mathrm{R}(\mathrm{ltm}) b$ parametresini kestirmede en düşük performası sergilemiştir. BILOG-MG programı 500 örneklem büyüklüğünde Mplus'a göre $b$ parametresini kestirmede daha iyi iken, 1000 örneklem büyüklüğünde Mplus programı BILOG-MG'ye göre daha iyidir. Örneklem büyüklügü 2000 iken BILOG-MG ve Mplus benzer performans sergilemiştir.

Araştırmadan çıkan bir diğer sonuç $s h(b)$ parametresini en iyi kestiren programın tüm örneklem büyüklüğ̈̈ ve test uzunluklarında BILOG-MG olduğu yönündedir. Öte yandan örneklem büyüklüğü arttıkça $s h(b)$ parametresine yönelik yanlılık indekslerinin tüm programlarda düştüğü görülmüştür. Toland (2008), sh (b) parametresinin BILOG-MG programında kestirim doğruluğunun 2 PL model için örneklem büyüklüğüne bağlı olduğunu belirtmiştir. Örneklem büyüklüğü 4000 olduğunda $s h(b)$ için tutarlı sonuçlar elde ettiğini, ancak örneklem büyüklüğü 500 iken büyük $b$ değerlerinde $s h(b)$ parametresinin kestirim doğruluğunun azaldığını ifade etmiştir.

RMSE değerleri dikkate alınarak $a$ parametresi incelendiğinde özellikle, küçük örneklemlerde 30 ve 60 madde sayısı koşullarında BILOG-MG programının en iyi performans sergilediği görülmüştür. Madde sayısı 30, örneklem büyüklükleri 1000 ve 2000 iken tüm programların perfromansı benzerdir. Madde sayıs1 60 iken, örneklem büyüklügü 1000 olduğunda Mplus en iyi kestirimi yaparken, 2000 örneklem büyüklüğünde BILOG-MG ve Mplus benzer performans göstermiştir. R (ltm) ise test uzunluğu 60 olduğunda en düşük performansı sergilemiştir.

$a$ parametresi için yanlılık değerlerine bakıldığında test uzunluğu 30 olduğunda Mplus programının en iyi, BILOG-MG programının kestirim doğruluğunun en kötü olduğu görülmüştür. Ancak madde sayısı 60'a çıkarıldığında BILOG-MG, Mplus kadar iyi yansız kestirim yapabilmektedir. R (ltm) ise en yanlı kestirim sonuçlarına sahiptir. sh (a) parametresi için RMSE değerlerine bakıldığında test uzunluğu 30, örneklem büyüklükleri 1000 ve 2000 iken BILOG-MG en iyi performansı gösterirken, Mplus ve $\mathrm{R}(\mathrm{ltm})$ 'nin performansları BILOG-MG'ye yakındır. Öte yandan test uzunluğu 60 ve örneklem sayısı büyük olduğunda BILOG-MG ve R (ltm) hem benzer hem de Mplus'tan daha doğru kestirim yapmaktadır. Toland (2008), BILOG-MG kullanıcılarının 2 PL modelde $a$ parametresinin küçük değerleri $(\mathrm{a}<1.4)$ için $\operatorname{sh}(a)$ 'nın kestirimine güvenebileceklerini belirtmiştir. Bu çalışmada elde ettiğimiz sonucun ilgili çalışma ile tutarlı olması, çalışmamızda $a$ parametresinin gerçek değerlerinin genel olarak 30 madde içerisinde yalnızca 4 tanesinde ve 60 madde içerisinde 13 tanesinde 1.4 değerinden küçük olmasından kaynaklanıyor olabileceğini akla getirmektedir.

Daha önce yapılmış çalışmalarda (Gao \& Chen, 2005; Kim, 2006; Yen, 1987), $a$ parametresi için elde edilen RMSE değerlerinin 0.11 ile 0.15 arasında, $b$ parametresi için 0.10 ile 0.14 arasında değiştiği belirtilmiştir. Bu çalışmada Mplus, BILOG-MG ve R (ltm) ile elde edilen RMSE değerleri yapılan çalışmalarla benzer aralıktadır. Dolayısıyla her üç programın da $a$ ve $b$ parametrelerini gerçek değere yakın kestirebilmesi nedeni ile kullanılabileceği önerilebilir. 